\title{
У THE BURNING OF CAPTIVES IN THE ASSYRIAN ROYAL INSCRIPTIONS, AND EARLY NEO-ASSYRIAN CONCEPTIONS OF THE OTHER
}

\author{
Ben Dewar \\ Independent Scholar
}

\begin{abstract}
This paper is a study of the topos of the king burning captives in the Assyrian royal inscriptions. This punishment is notable for both its rarity and its cruelty, being the only time that the royal inscriptions describe violence towards children. I approach this topic in terms of Donald Black's model of social control, in which the form and severity of social control, including violence, varies in relation to the "social geometry" that separates the parties involved in a dispute or conflict. I argue that in the royal inscriptions burning is inflicted on those that the Assyrians saw as "uncivilized": peoples inhabiting poorer cities in mountain regions who lacked the infrastructure necessary to stockpile prestige goods, such as precious metals, and were separated at a greater distance from Assyria by "social geometry" than other foreigners. These findings provide a useful insight into Assyrian conceptions of the other and give a better understanding of the variations in the severity of punishments inflicted by the Assyrians on their enemies.
\end{abstract}

\section{INTRODUCTION}

Death by burning is one of the more unusual punishments enacted upon Assyria's enemies in the Assyrian royal inscriptions, being notable for both its rarity and its severity. ${ }^{1}$ In Assyro-Babylonian thought, death by burning was one of the worst fates which might befall an individual; dying in such a manner denied access to the afterlife, as described by Enkidu in the Sumerian poem Gilgameš and the Netherworld (t1-t2, tr. George 2003: 776):

"Did you see the man who was burnt to death?" "I did not see him."

"His ghost is not there, his smoke went up to the heavens."

\footnotetext{
1 I am thankful to various participants in the Strange and Familiar conference for their insightful thoughts and comments on the research forming this paper-especially Eva Miller, who read and provided feedback on an early draft - and to Gina Konstantopoulos and the rest of ANEE for organizing and hosting such an excellent conference. I am also thankful to the two anonymous reviewers for their useful and informative feedback.

2 Anti-witchcraft texts sometimes present burning, carried out symbolically by burning a figurine representing a witch, as consigning that witch to the netherworld, but elsewhere these texts also present it in similar terms to Gilgameš and the Netherworld (Abusch 2002: 67-78; Schwemer 2010: 63-67).
}

Volume 9(2) (2021), pp. 67-81

DOI $10.23993 /$ store. 88852

Licensed under Creative Commons 4.0 (CC BY-NC-SA 4.0) license. 
This fate differs from others in the royal inscriptions that also result in the total destruction of an individual's remains, such as the bones of Nabû-šuma-ēreš, a rebellious governor of Nippur, being ground to dust (Novotny \& Jeffers 2018 no. 3: vi 79-85), or Tugdamme the Cimmerian melting away due to a wasting disease (Novotny \& Jeffers 2018 no. 23: 155-158), in that it is the Assyrian king who is described as performing the action. ${ }^{3}$ Not only does this method of execution deny access to the afterlife, but it is also the only punishment in the royal inscriptions to which the Assyrian king subjects children (see Table 1). The severity of death by burning is underlined by its rarity; the inscriptions of just four Assyrian kings-Tukultī-Ninurta I (12431207 BCE), Aššur-dān II (934-912 BCE), Ashurnasirpal II (883-859 BCE), and Shalmaneser III (858-824 BCE) - contain any definite occurrence of this topos, and only the inscriptions of Ashurnasirpal II record it occurring in more than one episode. ${ }^{4}$

We might therefore wonder if death by burning was applied to more severe transgressions against Assyria than other forms of violent punishment, such as impalement (see Radner 2015), but this does not appear to be the case. Only two of the instances of enemies executed by burning from the royal inscriptions are carried out in response to unusual transgressions against Assyria. Aššur-dān II burns Aramaeans of the Yausu tribe for encroaching into the Assyrian heartland (see below), the only instance described in the royal inscriptions of an "invasion" of Assyria during the reign of the incumbent king, whilst Ashurnasirpal II burns captive Assyrian settlers and their children from Kinabu following a rebellion in Halziluha, the only time in the royal inscriptions that Assyrians are explicitly stated to rebel against the incumbent king (Grayson 1991 A.0.101.1: i 101-103). The other instances of burning display no discernible differences from any usual Assyrian military campaigns. All of this makes the burning of captives in the royal inscriptions a topic deserving of further study.

There are various questions that might be asked about how frequently, and in what situations, enemies were burned by the Assyrians in reality. ${ }^{5}$ However, the extreme rarity of this topos in the inscriptions suggests that the Assyrian kings and their scribes felt comfortable representing this act in these texts in a very limited number of circumstances. ${ }^{6}$ This in turn suggests that any other instances of burning that might have occurred were not "acceptable" in the way that those

\footnotetext{
3 For example, the sons of Nabû-šuma-ēreš are made to perform the grinding of his bones (Novotny \& Jeffers 2018 no. 3: vi 79-85), distancing the king from the performance of the deed, whilst Tugdamme is struck down by the god Aššur (Novotny \& Jeffers 2018 no. 23: 157).

4 See below for a full list of attestations. The majority of these attestations date to the early Neo-Assyrian period, but one, from Tukultī-Ninurta I's inscriptions, is Middle Assyrian, and predates the others by several centuries. Note that I exclude the death of Šamaš-šuma-ukīn in a fire (Novotny \& Jeffers 2018 no. 11: iv 46-52; no. 23: 110-111) from this list; Ashurbanipal is not stated to have killed his rebellious brother, and Shana Zaia (2019) has recently convincingly argued that the Assyrian king deliberately stressed his lack of involvement in his Babylonian adversary's death in order to avoid suspicions that he had committed fratricide. Burning is also sometimes attested in other cuneiform sources as a punishment for various crimes. For a list of these other attestations, see Beaulieu 2009: 280-286.

5 For example, burning sometimes appears as a punishment in the curse formulae of Assyrian treaties. However, the burning is usually attributed to the gods (Parpola \& Watanabe 1988 no. 6: §62; no. 11: rev. 10-13). In instances when the burning is not explicitly attributed to the gods (such as Parpola \& Watanabe 1988 no. 6: §89), the presentation of the punishment as a curse implies that it will be enforced by the gods, the "metaphysical agents" (Assmann 1992: 47) responsible for enforcing the treaty curses. The Assyrian king is therefore disassociated from the actions performed in a similar fashion to the examples cited in $\mathrm{n}$. 3. The extent to which the Assyrian kings enacted punishments from the relevant treaty's curse formulae on rebels is considered in $n .12$ below.

6 In at least some instances, the Assyrian royal inscriptions would seem to have been produced by the king's chief scribe (Frahm 2003: 157-160; Pongratz-Leisten 2015: 329-330), but it is unclear whether this was the case for all inscriptions. For the king's role in the creation of royal inscriptions, see Frahm 2003: 157; Liverani 2014: 375-376.
} 
that were included in the royal inscriptions were. This paper will therefore focus primarily on the matter of the representation of burning in the inscriptions, as opposed to the application of this punishment in reality.

\section{“SOCIAL GEOMETRY” AND MORAL AND LEGAL RELATIVITY}

To begin with, we must acknowledge an important theoretical concept which will underpin the analysis in this paper: law, punishment, violence, and morality are all relativistic concepts. This point has often been acknowledged by scholars. For example, the anthropologist Marshall Sahlins (1972: 196-204) placed the relativity of morals in relation to social distance at the heart of his model of reciprocity, whilst Tzvetan Todorov makes a similar distinction between the treatment of individuals inhabiting the center and the periphery a key part of his definitions of both sacrifice and massacre. ${ }^{7}$

The relationship between an individual's social standing and identity and their treatment by others in various contexts has been extensively discussed by proponents of "pure sociology," most notably Donald Black. ${ }^{8}$ Pure sociology attempts to understand and explain human interactions in terms of their "social geometry," the distance between the parties involved in terms of their social status and level of intimacy with one another (Black 2007: 1292-1293). This concept has most extensively been explored in relation to social control, defined by Black (1984: 5) as "how people define and respond to deviant behaviour," including law and punishment. In the words of Bradley Campbell and Jason Manning (2019: 54):

\footnotetext{
The social geometry of a conflict explains the handling of the conflict. High-status disputants handle conflicts differently than low-status disputants do, and people with downward grievances handle them differently than people with upward grievances. Those who are socially close handle conflicts differently than those who are socially distant, and third parties respond to all these conflicts differently as well. ... Every conflict has a social configuration arising from different dimensions of social inequality and social distances, and it is this configuration - the social geometry - that makes certain responses more likely. ${ }^{9}$
}

This relativity of social control will not be entirely alien to Assyriologists; the Codex Hammurabi regularly displays a level of relativism in cases where the ruling differs in relation to the social class of the parties involved (Roth 1997: 72-73).

In spite of this, some studies on Assyrian violence toward enemies have considered the enemies' actions as the only factor in determining the type and severity of punishment which they should receive; their identity is not considered important. For example, Henry Saggs (1982: 87) argued in his seminal paper on Assyrian violence toward captives that the treatment

\footnotetext{
7 For Todorov (1984: 144), the victim of sacrifice "must not be too alien, too remote ... but he must not, on the other hand, belong to the same society," whilst in massacres "the more remote and alien the victims, the better." 8 Black's theoretical framework is presented in The Behavior of Law (Black 1976), and he has since elaborated and expanded on various aspects of the model (e.g., Black 1984; 1992; 1995; 2004).

9 I would, however, contest many of pure sociology's assertions. This approach has many problems which are similar or identical to those of structuralism (the erasure of individuality, an overly scientific outlook, the reduction of human action to the expression of pre-existent, overarching structures, etc.). Such clear-cut, scientistic approaches obscure the "fuzziness of historical reality" (Mackenthun 2008: 41). Furthermore, Douglas Marshall (2008) has characterized the scientism of pure sociology as decidedly unscientific, and Black's goal of "purifying" sociology as "unnecessary, undesirable, and unattainable" (Marshall 2008: 209). Nevertheless, social geometry is a useful tool to apply to questions of law, morality, and violence, provided we acknowledge, pace Black, that social geometry and social space are human inventions imposed upon social interactions by scholars as analytical tools, and not necessarily an inherent structural component of human interaction.
} 
of foreigners was entirely dictated by the actions that they had taken against Assyria. More recently, Mattias Karlsson (2016: 195) has argued that "actions and not essence determined the nature of the relationship between Assyria and the foreign lands - at least in the propaganda."

One problem with this approach is that it separates out identity and action in a manner that was not necessarily the case in the official ideology. Assyria's enemies are not-in the Assyrian view - simply people who resist, rebel, and act foolishly and arrogantly, but act in this fashion precisely because it is in their nature to be recalcitrant, rebellious, foolish, and arrogant. Enemies may be punished for their actions, but these actions are understood as resulting from the enemies' identity; they transgress against Assyria because they are enemies, not vice versa. ${ }^{10}$ To separate out action and identity so absolutely should therefore be avoided. ${ }^{11}$

Conversely, a consideration of the role of identity in determining the treatment of enemies is clearly present in Julian Reade's division of foreign states in Assyrian thought into four categories, each of which is treated differently, and subjected to differing levels of punishment for their transgressions against Assyria (Reade 1979: 333-334):

- Independent states considered to be equals with Assyria, which were usually treated in accordance with "international good manners," excluding some extraordinary circumstances.

- Independent states not considered equal to Assyria, where elaborate executions do not normally occur, and captives are "reasonably well treated."

- Independent peoples who did not conform to Assyrian "ideals of urban civilization," and who "were liable to be exterminated" by the Assyrians.

- Tributary states, where harsh punishments would be used by the Assyrians in response to rebellion.

Such a model clearly takes elements of "social geometry" into account; the political status and culture of foreign states are considered in addition to the actions which they perform. ${ }^{12}$

10 In this vein, Liverani (2014: 382-383) views the enemy's transgressions against Assyria as stemming from their "original sin" of being an enemy, whilst Oded (1992: 36) argues that in the official ideology the enemy is violent towards Assyria because "(i)t is in his nature to provoke violence constantly."

11 I am thankful to Eva Miller for this observation. Obviously, the actions of an enemy are not irrelevant when considering their punishment, but this facet of the picture has been the primary focus of the majority of the previous literature on Assyrian punishment of enemies. To redress the balance, this paper will be far more concerned with the identities of Assyria's enemies than their actions.

12 A third factor that may affect the treatment of rebels is that they have broken terms of their treaty with Assyria, and are thus punished under the terms of the treaty. For example, the punishment of a rebel's sons grinding their bones to dust that Ashurbanipal inflicts on Nabû-šuma-ēreš (see n. 3 above) is paralleled in the curse formulae of Esarhaddon's Succession Treaty (Parpola \& Watanabe no. 6: §47). However, the extent to which punishments from the treaty curse formulae were inflicted on treaty-breakers is uncertain. Many references to a vassal breaking their treaty terms in the royal inscriptions end with a punishment far more lenient than those described in the extant treaty curse formulae - many rebels and treaty-breakers are simply taken back to Assyria in fetters, sometimes to be displayed at the city gate (e.g., Fuchs 1993 Ann.: 68-70, 72-75, 201-202, 211-213; Grayson \& Novotny 2012 no. 22: iv 46-50; Leichty 2011 no. 1: iii 39-42, iv 25-31; Novotny \& Jeffers 2018 no. 11: x 6-39; Tadmor \& Yamada 2011 Tiglath-pileser III 47: obv. 19-20). It would therefore appear more likely that the punishments included in the treaty curses are the maximum possible punishment that the Assyrian king is allowed to impose in the case of particularly grievous or prolonged instances of rebellion. For example, Ashurbanipal saves the grinding of bones for the case of the rebel Nabû-šuma-ēreš, whom he accuses of deliberately undermining the peaceful relations between Assyria and Elam forged during the reign of his father, Esarhaddon (Waters 2000: 42-45), resulting in the first in a series of wars with Elam throughout Ashurbanipal's reign (for an overview of Assyrian-Elamite relations during Ashurbanipal's reign, see Waters 2000: 45-80). Furthermore, by the time of Nabû-šuma-ēreš' death c.664 BCE, the governors of Nippur had frequently acted rebelliously over a period of nearly two decades, from the early 670s to the late 660s BCE (Cole 1996: 53-55, 73-74), and during Esarhaddon's reign Nippur also appears to have been the center of operations for the rebel- 
Whilst I would dispute the extent to which "civilized" independent states were not subjected to exemplary punishment, ${ }^{13}$ Reade's categorization of states suggests the possibility that the severity with which enemies of Assyria were to be punished was influenced by the identity of those enemies at least some of the time. In this vein, I will proceed by considering some aspects of the identities of those subjected to burning in the Assyrian royal inscriptions.

\section{THE ATTESTATIONS OF THE TOPOS}

There are ten definite instances from the inscriptions in which the Assyrian king is stated to have executed enemies by burning them alive: ${ }^{14}$

- Tukulti-Ninurta I burns the inhabitants of a city in Purulimzu:

ma-ha-za GAL-a šá KUR.pu-ru-lim-zi ak-šud bal-țu-su-nu i-na IZI aq-lu

I conquered the great cult center of the land of Purulimzu. I burnt them (its inhabitants) alive with fire. (Grayson 1987 A.0.78.1: iii 42-44)

- Aššur-dān II burns members of the Yausu tribe of Aramaeans:

[... URU?]. 'MEŠ '-šu-nu DUMU.MEŠ-šu-nu i-na IZI.[MEŠ ášs-ru-up ...]

[I burnt] their [cities $]^{15}$ (and) their inhabitants (alternatively: [I burnt] their [...] (and) their sons) with fire. (Grayson 1991 A.0.98.1: 14-15)

- Ashurnasirpal II burns captives in seven different episodes from his inscriptions.

In Kinabu:

3 LIM šal-la-su-nu ina IZI.MEŠ GÍBIL [...] LÚ.ba-tu-li-šú-nu MUNUS.ba-tu-la-te-šú-nu a-na GÍBIL-te GÍBIL

3000 captives from them I burnt with fire [...] I burnt their boys (and) their girls as a burnt offering. (Grayson 1991 A.0.101.1: i 108-109)

In Mariru:

2 ME šal-la-su-nu ina IZI.MEŠ GÍBIL-up

200 captives from them I burnt with fire. (Grayson 1991 A.0.101.1: i 111)

In Tēla:

šal-la-su-nu HII.A.MEŠ ina IZI.MEŠ GÍBIL [...] LÚ.ba-tu-li-šú-nu MUNUS.ba-tu-la-te-šú-nu ana GÍBIL-te GÍBIL

Many captives from them I burnt with fire [...] I burnt their boys (and) their girls as a burnt offering. (Grayson 1991 A.0.101.1: i 116, ii 1; A.0.101.17: ii 1)

\footnotetext{
lious individual Șillaya (Frame 1992: 84-88). This prolonged Nippurian resistance to Assyrian rule made it one of the most rebellious parts of Babylonia during the 670s and 660s BCE (Cole 1996: 73), and this may have influenced Ashurbanipal's decision to destroy the remains of the dead governor. In light of this, it does not appear that punishments were carried out against an enemy only because they were included in the curse formulae of the treaty with Assyria that they had broken.

13 See, e.g., the beheadings of the Elamite king Teumman (Novotny \& Jeffers 2018 no. 3: v 95-96) and the Urarțian governor Andaria (Novotny \& Jeffers 2018 no. 3: iv 6-14) in the inscriptions of Ashurbanipal, the tower of heads erected at the Sam'alian city of Lutibu by Shalmaneser III (Grayson 1996 A.0.102.2: 62'), or the flaying of Babylonian citizens - possibly together with their king Marduk-balāssu-iqbi-in an inscription of Šamš̄i-Adad V (Grayson 1996 A.0.103.2: iv 9'-10'), all of which are exemplary punishments against people from independent states. Whilst the beheading of Teumman is characterized by Reade as occurring in extraordinary circumstances (Reade 1979: 333), the same cannot really be said of Shalmaneser III's actions at Lutibu. 14 The transliterations below are taken from the cited editions; the translations are my own.

15 This follows Grayson (1991: 133), but see n. 23 below.
} 
In Išpilipria:

LÚ.ba-tu-li-šú-nu MUNUS.ba-tu-la-te-šú-nu a-na GÍBIL-ti GÍBIL

I burnt their boys (and) their girls as a burnt offering. (Grayson 1991 A.0.101.1: ii 19; A.0.101.17: ii 62-63)

In Larbusa:

LÚ.ba-tul.MEŠ-šú-nu MUNUS.ba-tu-la-te-šú-nu a-na GÍBIL-te GÍBIL

I burnt their boys (and) their girls as a burnt offering. (Grayson 1991 A.0.101.1: ii 43; A.0.101.17: iii 13-14)

In Hudun:

LÚ.ba-tul.MEŠs-šú-nu MUNUS.ba-tu-la-ti-šú-nu ana GÍBIL-te GÍBIL

I burnt their boys (and) their girls as a burnt offering. (Grayson 1991 A.0.101.1: ii 57-58;

A.0.101.17: iii 50)

In Pitura:

ERIM.MEŠ TI.LA.MEŠ HुI.A.MEŠ ina ŠU DIB-ta si-ta-ti-šú-nu ina IZI.MEŠ GÍBIL-up [...] LÚ.ba-tu-li-šú-nu MUNUS.ba-tu-la-ti-šú-nu ana GÍBIL-te GÍBIL

I captured many of their troops alive. The rest of them I burnt with fire [...] I burnt their boys (and) their girls as a burnt offering. (Grayson 1991 A.0.101.1: ii 108-10; A.0.101.17:

iv 76-78, iv 82-83; A.0.101.19: 74-77)

- Shalmaneser III burns the inhabitants of Aridu:

LÚ.GURUŠ.TUR.MEŠ-šú-nu MUNUS.ba-tu-la-te-šú-nu a-na ma-aq-lu-te GÍBIL

I burnt their boys (and) their girls as a burnt offering. (Grayson 1996 A.0.102.2: i 17)

In addition, an annalistic text of Tiglath-pileser III (744-727 вCE) on a stone slab from Kalhu (Tadmor \& Yamada 2011 Tiglath-pileser III 7: 3) may provide an additional instance of the

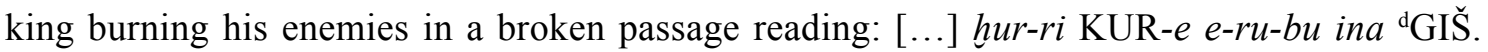
BAR aq-mu. Tadmor and Yamada (2011: 31) translate this passage as: "I burned with fire [the ... of the people (...) who] entered the ravines of the mountains." This reading is possible, but a more straightforward restoration would be to understand Tiglath-pileser III as burning those who fled to the ravines, as opposed to something in their possession. Of course, without a more complete duplicate of the text, who or what exactly was burnt must remain speculative. I will include this passage in the following analysis, but with the caveat that the occurrence of the burning of captives in it is not certain.

\section{EXCURSUS: DIFFERENCES IN THE TERMINOLOGY FOR THE BURNING OF ADULTS AND CHILDREN}

The above quotations make it clear that there is a difference in the vocabulary used in Ashurnasirpal II's inscriptions to describe the burning of adults and children. For adults, the standard terminology is the rather blunt and straightforward ina išati ašrup, "I burnt with fire," whereas the burning of children is described with the phrase ana maqlüte ašrup, "I burnt as a burnt offering." Karlsson (2016: 119-120) takes this as evidence that these instances of child murder were in fact a form of sacrifice: 
Some kings, but especially Ashurnasirpal II, refer to an act of burning adolescent boys and girls of unsubmissive, conquered cities... Sometimes this referring is added by (sic) the note that the said act served as a "burnt offering" (maqlütu)... Such an offering was normally based on sacrificed oxen, sheep, and doves, and it was made for the appeasing of deities... This atrocity then formed a part of the sacred, religiously motivated war.

However, I would argue that the description of these children as a "burnt offering" is more likely a metaphor. References to child sacrifice are extremely rare in first-millennium BCE Mesopotamia, and all of these references are best understood as rhetorical or metaphorical. ${ }^{16}$ Furthermore, if these instances of child burning represented a pious act, such as a burnt offering, we might expect to see the topos of burning children as maqlütu appear in far more than just four royal inscriptions in the entirety of Assyrian history, three of which contain duplicate accounts. We should therefore look for a different explanation for this difference in terminology.

To this end, I turn to the concept of "moral disengagement" as put forward by Albert Bandura (1999; Bandura et al. 1996). Bandura argues that an individual's morals are not constantly active, but can be "disengaged" in various ways to avoid "moral self-censure." In doing so, an individual can perform deeds that they would otherwise find morally repugnant with a clear conscience (Bandura et al. 1996: 364-366). One method of moral disengagement identified by Bandura is the use of euphemistic language:

Language shapes peoples' thought patterns on which they base many of their actions. Activities can take on markedly different appearances depending on what they are called. Euphemistic language thus provides a convenient tool for masking reprehensible activities or even conferring a respectable status upon them... Through sanitized or convoluted verbiage, destructive conduct is made benign and those engaged in it are relieved of a sense of personal agency. (Bandura et al. 1996: 365)

In this fashion, describing the children as a "burnt offering" allowed the king and his soldiers to morally disengage from acts of child murder, thus avoiding feelings of guilt, shame, and disgust that might otherwise have arisen from these actions. Furthermore, this euphemistic language also serves to make the child murder less immediate and shocking for the inscriptions' audiences. Of course, this does not explain why these instances of child murder were included in the inscriptions in the first place-the reasons for this will be explored below-but it does provide a reason for the differing descriptions of the burning of adults and children in Ashurnasirpal II's royal inscriptions.

16 The only other possible context, the burning of one's children in a temple as punishment for breaking a contract (the attestations of which are collected in Deller 1965; Schwemer 2001: 606), is almost certainly a rhetorical device demonstrating how strongly the parties intend to keep to the terms of the contract (Holm 2008: 89-90), and should be placed alongside such fantastical punishments as collecting large amounts of sahlî seeds off the ground with one's tongue or eating a mina of wool (Postgate 1973 no. 15: 28-31) as extremely unlikely to have occurred in reality (Joannès 2000: 207 n. 25). In this light, we might compare such extreme or fantastical punishments in Assyrian contracts to the English statement that, if an unlikely event should occur, "I'll eat my hat"; no one acting in good faith would expect the speaker to actually eat their own hat if the stated event came to pass. Deller (1965: 385-386) and Radner (1997: 211-219) instead view the "burning" in these contexts as a metaphor for the consecration of the children to the god in question. This interpretation is, to my mind, less convincing than that given by Holm and Joannès, which explains not only the instances of burning one's children as a punishment in Neo-Assyrian contracts, but also various other extreme or fantastical punishments included in these texts. 


\section{THE GEOGRAPHICAL DISTRIBUTION OF THE TOPOS}

A comparison of the episodes of death by burning in the royal inscriptions demonstrates a clear pattern in the geographical distribution of the victims of this punishment; all but one of the instances occur in regions in the mountains to the north or east of Assyria. These areas are often portrayed as inferior in the Mesopotamian literary tradition. The most famous examples from cuneiform literature are the Ummann-manda or the Gutians who descend from the mountains to cause the downfall of the Old Akkadian Empire in The Curse of Agade and The Cuthean Legend of Naräm-Sîn. These two texts portray these peoples as barely human, with the features of birds or monkeys (Cooper 1983: 56-57 lines 154-56; Westenholz 1997: 308-309 lines 31-35), whilst in the Weidner Chronicle (Glassner 2004: 266-67 line 64) the Gutians are ignorant of proper cultic practice. ${ }^{17}$ Furthermore, the Gutians are often described as either governing themselves without a king or being ruled by multiple kings, forms of government which were not acceptable from the Mesopotamian viewpoint (Dewar 2019: 149).

Similarly, the Assyrian sources present several possible examples of particularly hostile attitudes toward mountain-dwellers. The description of Rusa of Urarțu as a šaddh' $a$, "mountain man" in Sargon II's Letter to the God has been interpreted as an insult, ${ }^{18}$ whilst Ashurnasirpal II's description of the people of Sipirmena as wearing their hair "like women"19 has also been interpreted as a derogatory statement about these mountain-dwelling inhabitants of Zamua. ${ }^{20}$ Furthermore, Megan Cifarelli (1998: 224) highlights a scene from the Balawat Gates showing a group of soldiers from the north charging down a mountainside (King 1915: pl. XII). Some of these individuals are depicted as wearing nothing but their helmets and shields, something that is otherwise unknown in depictions of live, non-captive enemy soldiers on the battlefield in Assyrian art. ${ }^{21}$ Cifarelli (1998: 224) has interpreted this scene as emphasizing the alien nature of these mountain-dwellers:

\footnotetext{
I believe that the lack of association with cities in the portrayal of these non-Assyrians was certainly intended to signify their lack of "civilization." In addition, their behavior, posture, gesture, and costume identify them as the most emphatically outlandish, different, and non-Assyrian of all the non-Assyrians represented in this reign. ... Instead of the militarily superior bow and arrow, they wield spears, which defines them as being technologically inferior to the Assyrians. They run pell-mell down the slopes of the mountain toward the Assyrians, with their knees lifted and waving their arms high in the air. The antithesis of the Assyrian army in action, they are the strangest of all the non-Assyrian others appearing in this reign.
}

The correlation between the occurrence of death by burning and a location in the north or east would appear to be another example of such an attitude toward mountain-dwellers.

There is, however, one exception to this pattern. Although the region inhabited by the Yausu people is not stated by Aššur-dān II, they are clearly to be located to the south of the Assyrian

\footnotetext{
17 In Ashurbanipal's inscription from the Ištar Temple (Novotny \& Jeffers 2018 no. 23: 146), Tugdamme is similarly described as gu-tu-um.KI muš-tar-[hu] ša pa-lah DINGIR.[MEŠ] 'la? $i$-du-ú, "an arrogant Gutian who does not know how to fear the gods."

18 Lanfranchi 2003: 85; Van De Mieroop 2010: 423. Ashurbanipal similarly describes Tugdamme as 'LUGAL' $\check{s} a d-d a-a-a-u$, "king of the mountain people" (Novotny \& Jeffers 2018 no. 23: 146).

19 Grayson 1991 A.0.101.1: ii 75-76. Earlier translations (e.g., Budge \& King 1902: 321; Luckenbill 1926: 153) interpret this passage as describing the men of Sipirmena's speech rather than their hair.

20 Karlsson 2016: 241; Lanfranchi 2003: 85-86. Lanfranchi views this passage as an allusion to the description of the wild and uncivilized Enkidu's hair in the Standard Babylonian Epic of Gilgameš (George 2003: 544-545 tablet I: 106), and therefore views it as a comment on the people of Sipirmena's uncivilized nature.

21 For other instances of naked, live northerners in battle in scenes from the Balawat Gates, see Curtis \& Tallis 2008: 160-161 figs. 59-60; King 1915: pls. X-XI.
} 
heartland; their journey into Assyria is described with the verb el $\hat{u}$ 'to go up,' implying travel up the Tigris (Younger 2016: 224), whilst the name of their settlement, Ekal-pī-nāri, "Palace of the Mouth of the River," suggests a location at the confluence of the Lower Zab and the Tigris (Lipiński 2000: 412). An explanation for this deviation from the pattern present in the other instances of captives being burnt is provided by the fact that the Yausu have committed the serious crime, in the Assyrian view, of invading the Assyrian heartland. This transgression, unique in the royal inscriptions, was apparently serious enough to warrant a punishment for this Aramaean tribe which was normally reserved for mountain-dwellers.

\section{ECONOMIC FACTORS}

Geographical location is the most obvious factor which presents itself in the social geometry of the burning of captives, but it is not the only factor which we might analyze. Unfortunately, these other factors become difficult to assess due to variations in the level of detail given in the royal inscriptions of different kings. However, we are somewhat lucky in this regard to have a large number of the instances of burning come from the inscriptions of a single king; Ashurnasirpal II's inscriptions provide seven of the eleven relevant episodes. The identity of this king is also fortuitous. Ashurnasirpal's annals contain an unusually high level of detail in describing the goods taken from the various polities that he encountered on campaign. This peculiarity of this king's inscriptions has allowed Mario Liverani (1992: 155-162) to undertake a fairly extensive study of the economic geography of the Ancient Near East during Ashurnasirpal's reign. It would therefore seem useful to similarly analyze the booty taken from settlements where captives were burnt.

The table below (Table 1) clearly demonstrates that booty listed as taken from the locations of the burning of captives is limited to captives, livestock, and the somewhat ambiguous "possessions" ( $(\bar{u} \bar{s} u)$. Metals are conspicuously missing from the lists of goods taken, even in the inscriptions of Ashurnasirpal II, whose tribute lists are more exhaustive than most. The ability to give metal as tribute is identified by Liverani (1992: 160-161) as one thing which distinguishes the more complex kingdoms encountered by Ashurnasirpal from "chiefdoms." 22 The only definite instance of metal given as tribute by any of the settlements where the burning of captives occurs comes in the form of bronze cauldrons from Nirbu (see nn. 25-26 below). Liverani (1992: 161-162) argues that these objects differ from other forms of metal in that they are widely used across the region in the first millennium in ceremonial contexts, and therefore appear in the tribute of settlements otherwise lacking in stockpiles of metals.

\footnotetext{
22 Liverani (1992: 125-130) uses the term "chiefdom" in opposition to "kingdom." He identifies "kingdoms" in Ashurnasirpal's inscriptions by the presence of a king ( $\breve{s} a r r u)$ and a three-tiered settlement system of royal city ( $\bar{a} l \grave{s} a r r u \bar{t} t i$, the kingdom's capital), fortified city (ăl dannūti, a walled, defensible site or important regional center), and surrounding cities (ālāni ša limēti, unwalled villages and other small settlements), whilst his "chiefdoms" possess only fortified cities and surrounding cities and have no king (any named leader is a nasīku 'sheikh,' or similar, or is afforded no title, Liverani 1992: 125-130). These distinctions can be difficult to identify in the inscriptions. Ashurnasirpal frequently provides no qualification for the type of city described (e.g., Grayson 1991 A.0.101.1: i 59-61, i 75-79, iii 2-16). Similarly, individual rulers (both those identified by Liverani as "kings" and "chiefs") are often given no qualifying title (e.g., Grayson 1991 A.0.101.1: i 96, ii 12-13, ii 40). However, this distinction does generally seems to hold up for the burning of captives; none of the settlements where burning occurs are ever described as "royal cities" and none of their rulers (in the instances where rulers are mentioned) are ever explicitly "kings."
} 
Table 1 Settlements where captives are burned in the Assyrian Royal Inscriptions.

\begin{tabular}{|c|c|c|c|c|c|c|c|}
\hline & $\underline{\text { Settlement(s) }}$ & Direction & $\frac{\text { Victims of }}{\underline{\text { Burning }}}$ & $\begin{array}{l}\text { Booty and/or } \\
\text { captives (šallatu) }\end{array}$ & $\frac{\text { Oxen }}{(\text { alpu })}$ & $\begin{array}{l}\text { Sheep and } \\
\text { goats }(\text { sènu) }\end{array}$ & $\begin{array}{l}\text { Possessions } \\
\underline{(b \bar{u} \breve{s} u)}\end{array}$ \\
\hline 害当 & $\begin{array}{l}\text { The "great cult } \\
\text { center" }(m \bar{a} h \bar{a} z a) \\
\text { of Purulimzu }\end{array}$ & North & $\begin{array}{l}\text { Not stated } \\
\text { (presumably } \\
\text { adults) }\end{array}$ & $\mathrm{x}$ & & & \\
\hline 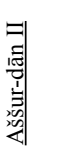 & The Yausu & South & $\begin{array}{l}\text { Either } \\
\text { "citizens" or } \\
\text { children }^{23}\end{array}$ & $?^{24}$ & & $\mathrm{x}$ & \\
\hline \multirow{7}{*}{ 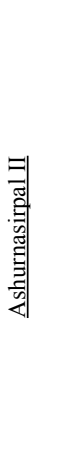 } & Kinabu & North & $\begin{array}{l}\text { Adults and } \\
\text { children }\end{array}$ & & & & \\
\hline & Mariru & North & Adults & $\mathrm{x}$ & $\mathrm{x}$ & $\mathrm{x}$ & \\
\hline & $\begin{array}{l}\text { Tēla/people of } \\
\text { Nirbu }^{25}\end{array}$ & North & $\begin{array}{l}\text { Adults and } \\
\text { children }\end{array}$ & $\mathrm{x}$ & $\mathrm{x}$ & $\mathrm{x}$ & $\mathrm{x}$ \\
\hline & $\begin{array}{l}\text { Išpilipria/ people } \\
\text { of Nirbu }\end{array}$ & North & Children & $\mathrm{x}$ & & & $\mathrm{x}$ \\
\hline & Larbusa & East & Children & $\mathrm{x}$ & $\mathrm{x}$ & $\mathrm{x}$ & $\mathrm{x}$ \\
\hline & Hudun $^{26}$ & East & Children & $\mathrm{x}$ & $\mathrm{x}$ & $\mathrm{x}$ & \\
\hline & Pitura & North & $\begin{array}{l}\text { Adults and } \\
\text { children }\end{array}$ & $\mathrm{x}$ & & & \\
\hline 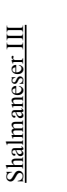 & Aridu & North & Children & $\mathrm{x}$ & & & \\
\hline 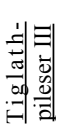 & $\begin{array}{l}\text { Settlements } \\
\text { near Mount } \\
\text { Hulihadri }^{27}\end{array}$ & East & Unclear $^{28}$ & & & & \\
\hline
\end{tabular}

23 Grayson (1991: 133) restores [...URU(?).M]EŠ-šu-nu DUMU.MEŠ-šu-nu i-na IZI.[MEŠ ašrup ...] and translates this as "[I] burnt [(.. and)] their [cities] (with) their inhabitants." This seems unlikely in light of the fact that only the only settlements mentioned in surviving parts of the passage are maškannate 'tents' (see n. 29 below), and the single larger settlement Ekal-pī-nāri (written with the determinative URU 'city'). If settlements or dwellings are referred to in the broken passage, then it would seem that maškanātešunu 'their tents,' written earlier in the passage as $m$ ] aš-kan-na-te.MEŠ-šs-nu (Grayson 1991 A.0.98.1: 11), would be a more likely reading. Without knowing for certain what the lost first noun is, it is also possible that DUMU.MEŠ- $\check{u} u-n u$ should be read as 'their sons' rather than 'their inhabitants.' However, the burning of children in the inscriptions of Ashurnasirpal II and Shalmaneser III is consistently described with the phrase ana maqlüte ašrup, "I burnt as a burnt offering," whilst ina išăti ašrup, "I burnt with fire," is used for the burning of adult captives (see the discussion above). This might suggest that Aššur-dān here describes the burning of adults, but that is far from certain. 24 Grayson tentatively restores [... šallassunu kabitta] in the final line of this campaign account (Grayson 1991 A.0.98.1: 15).

25 The inhabitants of Nirbu later give Ashurnasirpal horses, mules, oxen, sheep, wine, and bronze cauldrons (Grayson 1991 A.0.101.1: ii 9-12).

26 Hudun is later one of a group of polities, together with Huartišu, Hubuškia and Gilzānu who give tribute to Ashurnasirpal consisting of silver, gold, horses, multi-colored garments, oxen, sheep, and wine (Grayson 1991 A.0.101.1: ii 80-81). However, this list is the sum of the tribute given by all of these polities, and Hudun need not have contributed to all aspects of it. Hubuškia and Gilzānu give gold and silver as part of their tribute in a prior campaign account (Grayson 1991 A.0.101.1: i 56-57), and the absence of these goods from the booty taken from Hudun during the campaign there suggests that the precious metals were supplied by the two better-known kingdoms in the list. 27 The possibility that this passage may describe the burning of captives is addressed above.

28 See the discussion of this passage above. 
It would seem, then, that the burning of captives occurred in the "less developed" parts of the regions to the north and east of Assyria. I would therefore suggest that this pattern in the economic status of settlements where captives are burnt illustrates some aspects of the Assyrian conception of the "mountain man." In less wealthy settlements that lacked the institution of kingship, as understood by the Assyrians, which did not possess the infrastructure necessary for the stockpiling of metals and other goods and held wealth primarily in the form of their livestock, burning was apparently an acceptable punishment. In the one instance outside of the mountains, Aššur-dān's burning of the Yausu, the victims are nomadic or semi-nomadic — some proportion of them live in maškanāte 'tents' ${ }^{29}$ (Younger 2016: 224) — and appear to have little wealth for plundering beyond livestock. ${ }^{30}$

By contrast, in wealthier kingdoms with stockpiles of metals and prestige goods, which were closer to the Assyrian idea of what cities and states should be, burning was not an appropriate punishment. Social geometry (see above) separated Assyria from less wealthy, less "civilized" peoples in the north and east by a greater distance than it did for others. Punishments which might have been too extreme to apply to most of the king's enemies were therefore acceptable for use at least some of the time in these regions. Less wealthy settlements provided fewer economic gains to Assyria, and there was thus less of an incentive to avoid destroying their population. Burning captives was a punishment that, in addition to its extreme cruelty, robbed a settlement of its next generation of workers, significantly harming its ability to recover in the long term from the damage dealt to it by Assyria. This in turn reduced the economic output of the settlement in question, and accordingly the amount of tribute which it could give to Assyria. This was less damaging to Assyrian state income from tribute when applied in settlements which had little to offer to Assyria in economic terms in the first place.

\section{THE RARITY OF THE TOPOS}

There is, of course, still the fact that burning is not used in all situations where the two factors discussed above are present to consider. It may be that there are various other aspects of "social geometry" which influenced the decision to burn captives or not, or at least whether to include this detail in the royal inscriptions, which are obscured by the nature of the sources. Furthermore, pure sociology takes a somewhat mechanistic view of human interactions, considering social behaviors in terms of how "social life" behaves as opposed to how individuals behave, and this peculiarity of its approach removes people from the equation. ${ }^{31}$ The current study is concerned

\footnotetext{
29 Younger 2016: 224. Grayson (1991: 132) instead translates this term as "settlements," but the CAD (s.v. maškanu [2]) gives only three other attestations of maškanu with this meaning, two of which are read differently in more recent translations (Moran 1992: 344 with n. 6; Parpola 1987: 107), whilst the third, from another Assyrian royal inscription, concerns the massacre of the Utu Aramaeans (Grayson 1991 A.0.100.5: 49-50), and maškanāte in this context is also understood by Younger (2016: 72-73) to refer to tents.

30 The captives from Kinabu would seem to be Assyrians; this settlement belonged to Halziluha, which had been populated with Assyrian settlers by Shalmaneser I or II (Grayson 1991 A.0.101.1: i 102-103). The burning of captives here might therefore seem to contradict the theory outlined above. However, I have argued in my doctoral dissertation (Dewar 2019: 182-183) that the account of the rebellion in Halziluha presents the Assyrian settlers there as having been "de-Assyrianized" as a result of their isolation from Assyria during the period of decline in the late Middle Assyrian period (I have since elaborated on this argument, taking the findings of the present paper into account, in Dewar 2020: 115-117). Their treatment in this fashion signifies the fact that they have become akin to the surrounding mountain peoples during this decline. Burning was therefore a suitable punishment under the circumstances.

31 See n. 9 above. Black (1995: 869-870) argues that this is one of pure sociology's greatest strengths.
} 
with texts which display, to a greater or lesser extent, some degree of artistic expression and editorial decision-making on the part of their authors. Textual accounts of social interactions are not, of course, the social interactions themselves, and editorial decisions by the king and his scribes can skew the record in ways that do not necessarily reflect the reality of the situation. We might, for example, wonder whether the concentration of the topos of burning captives in the inscriptions of just four or five kings is not representative of decisions by individual kings and their scribes about what should or should not be included in these texts. The compositional and stylistic choices of individuals involved in the production of the royal inscriptions cannot always be neatly explained as reactions to specific circumstances, and personal preference may contribute in part to the uneven chronological distribution of the topos of burning captives in the royal inscriptions.

That being said, several interesting details might be highlighted whilst attempting to fathom the concentration of the topos in the texts of a small number of kings. Almost all of the attestations of burning relate to either Mount Kašiyari in the northwest or Zamua in the east. Both of these regions are campaigned in during the early Neo-Assyrian period, but appear to have been firmly under Assyrian control by the end of Shalmaneser III's reign, and no campaigns there are attested in inscriptions of the Sargonid period (721-627 BCE). This fact might be partially responsible for the lack of this topos in Sargonid texts. Assyria's campaigns in these areas after this point are primarily directed toward wealthier and more prestigious states such as Mannea, Mușașir, and Subria. ${ }^{32}$ Furthermore, there is a trend in Sargonid royal inscriptions toward focusing on the punishment of individual leaders rather than the people as a whole (Bagg 2016: 59 fig. 6.1; Dalley 2017: 528). In the royal inscriptions, burning is never used as a punishment for individuals, only groups, as seen in the previously quoted examples. For individuals, other punishments, such as flaying, are used instead (Bagg 2016: 59 fig. 6.1). The lower frequency of punishments for groups of people in later Neo-Assyrian royal inscriptions may also have contributed to the absence of the topos of burning captives in Sargonid texts.

\section{CONCLUSION}

This study has been built on a fortunate situation in which the majority of the attestations of the burning of captives occur in the royal inscriptions of a king whose inscriptions are unusually detailed with regard to the goods taken on campaign. This has allowed for more details of the social geometry of the relevant conflicts to be determined. In turn, a more detailed understanding of the social geometry has allowed me to identify a correlation between the burning of captives and "less developed" mountain regions to Assyria's north and east. This correlation would seem to be a result of Assyrian prejudice toward those mountain-dwelling peoples who did not conform to the Assyrian ideal of civilisation: urban, inhabited lowland areas that possessed the institution of kingship.

It would seem fitting to end this paper by returning to Julian Reade's categorization of foreigners in Assyrian thought outlined above. Reade's (1979: 334) third category is of particular interest for the current purpose:

32 On the Sargonid campaigns to these regions, see RlA s.v. Mannäer §3, Mușașir A §2, Šubria §3. 
people who denied allegiance both to the Assyrian king and to the ideals of urban civilization which the Assyrians and other states upheld. These were the wild tribes and villagers of hill and desert; they were liable to be exterminated.

The description of these peoples as "liable to be exterminated" by the Assyrians would seem to hold up for instances of the burning of captives; only two of the settlements where captives are burnt in the definite attestations of the topos from the early Neo-Assyrian royal inscriptions, Hudun (Grayson 1991 A.0.101.1: ii 80) and Aridu (Grayson 1996 A.0.103.1: ii 12), are attested in the inscriptions after the campaigns in which their inhabitants were subjected to this punishment. Most of these settlements may never have recovered from the loss of life-often including the next generation of the workforce - that they had suffered at the hands of the Assyrian army. Younger (2016: 224) has characterized Aššur-dān II's actions against the Yausu as a "massive extermination." In light of the discussion above, we might perhaps view the other instances of the burning of captives, and especially the burning of children, in a similar way.

\section{REFERENCES}

Abusch, Tzvi 2002. Considerations When Killing a Witch: Developments in Exorcistic Attitudes to Witcheraft in Mesopotamia. In: T. Aвusch (ed.), Mesopotamian Witchcraft: Toward a History and Understanding of Babylonian Witchcraft Beliefs and Literature (Ancient Magic and Divination 5): 65-78. Leiden: Brill.

Assmann, Jan 1992. Inscriptional Violence and the Art of Cursing: A Study in Performative Writing. Stanford Literature Review 8: 43-65.

BAGG, Ariel M. 2016. Where is the Public? A New Look at the Brutality Scenes in Neo-Assyrian Royal Inscriptions and Art. In: L. BAtTini (ed.), Making Pictures of War: Realia et Imaginaria in the Iconology of the Ancient Near East (Archaeopress Ancient Near Eastern Archaeology 1): 57-82. Oxford: Archaeopress.

Bandura, Albert 1999. Moral Disengagement in the Perpetration of Inhumanities. Personality and Social Psychology Review 3(3): 193-209.

Bandura, Albert, Claudio Barbaranelli, Gian Vittorio Caprara \& Concetta Pastorelli 1996. Mechanisms of Moral Disengagement in the Exercise of Moral Agency. Journal of Personality and Social Psychology 71(2): 364-374.

Beaulieu, Paul-Alain 2009. The Babylonian Background to the Motif of the Fiery Furnace in Daniel 3. Journal of Biblical Literature 128(2): 273-290.

BLACK, Donald 1976. The Behavior of Law. NY: Academic Press.

Black, Donald 1984. Social Control as Dependent Variable. In: D. Black (ed.), Toward a General Theory of Social Control, I: Fundamentals: 1-36. Orlando: Academic Press.

BLACK, Donald 1992. Social Control of the Self. Virginia Review of Sociology 1: 39-49.

Black, Donald 1995. The Epistemology of Pure Sociology. Law and Social Inquiry 20(3): 829-870.

Black, Donald 2004. Violent Structures. In: M.A. Zahn, H.H. Brownstein \& S.L. Jackson (eds), Violence: From Theory to Research: 145-158. Newark: LexisNexis.

Black, Donald 2007. Relativity, Legal. In: D.S. Clark (ed.), Encyclopaedia of Law and Society: 1292-1294. Thousand Oaks: Sage Publications.

Budge, E.A.Wallis \& L.W. KIng 1902. Annals of the Kings of Assyria: The Cuneiform Texts with Translations, Transliterations, etc., from the Original Documents in the British Museum, I. London: British Museum.

Campbell, Bradley \& Jason Manning 2019. Social Geometry and Social Control. In: M. Deflem (ed.), The Handbook of Social Control: 50-62. Hoboken, NJ: Wiley Blackwell.

Cifarelli, Megan 1998. Gesture and Alterity in the Art of Ashurnasirpal II of Assyria. The Art Bulletin 80(2): 210-228.

Cole, Steven W. 1996. Nippur in Late Assyrian Times. (State Archives of Assyria Studies 4) Helsinki: Neo-Assyrian Text Corpus Project.

Cooper, Jerrold S. 1983. The Curse of Agade. (Johns Hopkins Near Eastern Studies) Baltimore: Johns Hopkins University Press.

Curtis, John E. \& Nigel Tallis (eds) 2008. The Balawat Gates of Ashurnasirpal II. London: British Museum. 
Dalley, Stephanie 2017. Assyrian Warfare. In: E. Frahm (ed.), A Companion to Assyria (Blackwell Companions to the Ancient World): 522-533. Hoboken, NJ: Wiley Blackwell.

Deller, Karlheinz 1965. Review of Roland de Vaux, Les sacrifices de l'Ancien Testament. Orientalia, Nova Series 34(3): 382-386.

Dewar, Benjamin Neil 2019. Representations of Rebellion in the Assyrian Royal Inscriptions. PhD dissertation, University of Birmingham.

Dewar, Benjamin Neil 2020. Us against Them: Ideological and Psychological Aspects of Ashurnasirpal II's Campaign against Assyrian Rebels in Halziluha. Iraq 82: 111-124.

FrAHM, Eckart 2003. New Sources for Sennacherib's "First Campaign.” ISIMU 6: 129-164.

Frame, Grant 1992. Babylonia 689-627 BC: A Political History. (Publications de l'Instituut historique-archéologique néerlandais de Stamboul 69) Leiden: Nederlands Instituut voor het Nabije Oosten.

Fuchs, Andreas 1993. Die Inschriften Sargons II. aus Khorsabad. Göttingen: Cuvillier.

George, Andrew R. 2003. The Babylonian Gilgamesh Epic: Introduction, Critical Edition and Cuneiform Texts. Oxford: OUP.

GLASSNER, Jean-Jacques 2004. Mesopotamian Chronicles. (Writings from the Ancient World 18) Atlanta: Society of Biblical Literature.

Grayson, A. Kirk 1987. Assyrian Rulers of the Third and Second Millennia BC (to 1115 BC). (Royal Inscriptions of Mesopotamia, Assyrian Periods 1) Toronto: University of Toronto Press.

Grayson, A. Kirk 1991. Assyrian Rulers of the Early First Millennium BC I (1114-859 BC). (Royal Inscriptions of Mesopotamia, Assyrian Periods 2) Toronto: University of Toronto Press.

Grayson, A. Kirk 1996. Assyrian Rulers of the Early First Millennium BC II (858-745 BC). (Royal Inscriptions of Mesopotamia, Assyrian Periods 3) Toronto: University of Toronto Press.

Grayson, A. Kirk \& Jamie Novotny 2012. The Royal Inscriptions of Sennacherib, King of Assyria (704-681 BC), I. (Royal Inscriptions of the Neo-Assyrian Period 3(1)) Winona Lake, IN: Eisenbrauns.

Holm, Tawny L. 2008. The Fiery Furnace in the Book of Daniel and the Ancient Near East. Journal of the American Oriental Society 128(1): 85-104.

JoANNÈs, Francis 2000. Une chronique judiciaire d'époque hellénistique et le châtiment des sacrilèges à Babylone. In: J. Marzahn \& H. Neumann (eds), Assyriologica et Semetica: Festschrift für Joachim Oelsner anläßlich seines 65. Geburstages am 18. Februar 1997 (Alter Orient under Altes Testament 252): 193-211. Wiesbaden: Ugarit.

KarLSSon, Mattias 2016. Relations of Power in Early Neo-Assyrian State Ideology. (Studies in Ancient Near Eastern Records 10) Boston: De Gruyter.

KING, L.W. 1915. Bronze Reliefs from the Gates of Shalmaneser, King of Assyria BC 860-825. London: British Museum.

LANFRANCHI, Giovanni B. 2003. The Assyrian Expansion in the Zagros and the Local Ruling Elites. In: G.B. Lanfranchi, M. Roaf \& R. Rollinger (eds), Continuity and Empire (?): Assyria, Media, Persia (History of the Ancient Near East/Monographs 5): 79-118. Padova: S.a.r.g.o.n.

LeICHTY, Erle 2011. The Royal Inscriptions of Esarhaddon, King of Assyria (680-669 BC). (Royal Inscriptions of the Neo-Assyrian Period 4) Winona Lake, IN: Eisenbrauns.

LipiŃski, Edward 2000. The Aramaeans: Their Ancient History, Culture, Religion. (Orientalia Lovaniensia Analecta 100) Leuven: Peeters.

LiVerani, Mario 1992. Studies on the Annals of Aššurnasirpal II 2: Topographical Analysis. (Quaderni di geografia storica 4) Rome: Università di Roma "La Sapienza."

Liverani, Mario 2014. The King and His Audience. In: S. Gaspa, A. Greco, D.M. Bonacossi, S. Ponchia \& R. Rollinger (eds), From Source to History: Studies on Ancient Near Eastern Worlds and Beyond Dedicated to Giovanni Battista Lanfranchi on the Occasion of His 65th Birthday on June 23, 2014 (Alter Orient under Altes Testament 412): 373-385. Münster: Ugarit.

Luckenbill, Daniel David 1926. Ancient Records of Assyria and Babylonia, I: Historical Records of Assyria from the Earliest Times to Sargon. Chicago: UCP.

Mackenthun, Gesa 2008. Storytelling as Cultural Survival in Leslie Silko's “Ceremony.” In: C. Schmitt (ed.), Erzählkulturen im Medienwandel: 39-52. Münster: Waxmann. 
Marshall, Douglas A. 2008. The Dangers of Purity: On the Incompatibility of "Pure Sociology" and Science. The Sociological Quarterly 49(2): 209-235.

Moran, William L. 1992. The Amarna Letters. Baltimore: Johns Hopkins University Press.

Novotny, Jamie \& Joshua JefFers 2018. The Royal Inscriptions of Ashurbanipal (668-631 BC), Aššur-etel-ilāni (630-627 BC), and Sin-šarra-iškun (626-612 BC), Kings of Assyria, I. (Royal Inscriptions of the Neo-Assyrian Period 5(1)) Winona Lake, IN: Eisenbrauns.

ODED, Bustenay 1992. War, Peace and Empire: Justifications for War in the Assyrian Royal Inscriptions. Wiesbaden: Dr. Ludwig Reichert.

Parpola, Simo 1987. The Correspondence of Sargon II, I: Letters from Assyria and the West. (State Archives of Assyria 1) Helsinki: Neo-Assyrian Text Corpus Project.

Parpola, Simo \& Kazuko Watanabe 1988. Neo-Assyrian Treaties and Loyalty Oaths. (State Archives of Assyria 2) Helsinki: Neo-Assyrian Text Corpus Project.

Pongratz-Leisten, Beate 2015. Religion and Ideology in Assyria. (Studies in Ancient Near Eastern Records 6) Berlin: De Gruyter.

Postgate, J. Nicholas 1973. The Governor's Palace Archive. (Cuneiform Texts from Nimrud 2) London: British School of Archaeology in Iraq.

RAdner, Karen 1997. Die neuassyrischen Privatrechtsurkunden als Qulle für Mensch und Umwelt. (State Archives of Assyria Studies 6) Helsinki: Neo-Assyrian Text Corpus Project.

RAdNER, Karen 2015. High Visibility Punishment and Deterrent: Impalement in Assyrian Warfare and Legal Practice. Zeitschrift für Altorientalische und Biblische Rechtsgeschichte 21: 103-128.

Reade, Julian 1979. Ideology and Propaganda in Assyrian Art. In: M.T. Larsen (ed.), Power and Propaganda: A Symposium on Ancient Empires (Mesopotamia 7): 329-343. Copenhagen: Akademisk Forlag.

Rотн, Martha T. 1997. Law Collections from Mesopotamia and Asia Minor (Writings from the Ancient World 6). 2nd edn. Atlanta: Society of Biblical Literature.

SAGgS, H.W.F. 1982. Assyrian Prisoners of War and the Right to Live. In: H. Hirsch \& H. Hunger (eds), Vorträge gehalten auf der 28. Rencontre Assyriologique Internationale in Wien, 6.-10. Juli 1981: 85-93. (Archiv für Orientforschung Beiheft 19) Horn: Ferdinand Berger \& Söhne.

Sahlins, Marshall 1972. On the Sociology of Primitive Exchange. In: M. SAhlins (ed.), Stone Age Economics: 185-275. Chicago: Aldine Atherton.

SCHWEMER, Daniel 2001. Die Wettergottgestalten Mesopotamiens und Nordsyriensim Zeitalter der Keilschriftkulturen: Materieln und Studien nach den schriftlichen Quellen. Wiesbaden: Harrasowitz.

Schwemer, Daniel 2010. Entrusting the Witches to Humut-tabal: The ušburruda Ritual BM 47806+. Iraq 72: 63-78.

TADMOR, Hayim \& Shigeo YAMADA 2011. The Royal Inscriptions of Tiglath-pileser III (744-727 BC), and Shalmaneser $V(726-722$ BC), Kings of Assyria. (Royal Inscriptions of the Neo-Assyrian Period 1) Winona Lake, IN: Eisenbrauns.

Todorov, Tzvetan 1984. The Conquest of America: The Question of the Other. Tr. R. Howard. NY: Harper Perennial.

Van De Mieroop, Marc 2010. A Study in Contrast: Sargon of Assyria and Rusa of Urartu. In: S.C. Melville \& A.L. Slotsky (eds), Opening the Tablet Box: Near Eastern Studies in Honor of Benjamin R. Foster (Culture and History of the Ancient Near East 42): 417-434. Leiden: Brill.

Waters, Matthew W. 2000. A Survey of Neo-Elamite History. (State Archives of Assyria Studies 12) Helsinki: Neo-Assyrian Text Corpus Project.

Westenholz, Joan Goodnick 1997. Legends of the Kings of Agade. (Mesopotamian Civilizations 7) Winona Lake, IN: Eisenbrauns.

Younger, Kurt Lawson Jr. 2016. A Political History of the Arameans: From Their Origins to the End of Their Polities. Atlanta: SBL Press.

ZAIA, Shana 2019. My Brother's Keeper: Assurbanipal versus Šamaš-šuma-ukīn. Journal of Ancient Near Eastern History 6(1): 19-52. 